\title{
OBSERVATIONS ON THE GEOGRAPHICAL DISTRIBUTION OF TOPONYMIC ENDINGS IN ESTONIA
}

\author{
Peeter Päll \\ Institute of the Estonian Language
}

\begin{abstract}
The article looks at the geographical distribution of toponymic endings with the aim of discovering significant patterns. The corpus includes ca. 9,000 oikonyms, of which $24 \%$ are those that have the analysed endings. Endings are recognized if names have at least 3 syllables or have 2 syllables and the Q3 degree of quantity; in these cases the existence of a toponymic suffix is most likely. In the case of endings that have multiple origins there are seemingly no specific distribution patterns, with the exception of some borrowed endings (e.g. $-n a$ or $-v a$ ). In the case of typical toponymic suffixes -la, -ste and -vere each of these are often concentrated into certain areas based on which the whole are of Estonia might be divided into regions: -vere-region (northern Tartumaa and northern Viljandimaa), -ste-region (Võrumaa, southern Tartumaa, southern Viljandimaa and southern Pärnumaa), -la-region (Virumaa, Järvamaa, Harjumaa) and a mixed region (Läänemaa, northern Pärnumaa). The island of Saaremaa is dominated by -la-endings, Hiiumaa is either a mixed region or a -ste-region.
\end{abstract}

Keywords: toponyms, toponymic suffixes, toponymic geography, etymology

\section{Terms and previous studies}

Research into the geographical distribution of onymic elements (toponymic, anthroponymic etc.) may be called areal onomastics, based on the wider discipline of areal linguistics; a near synonym would be onomastic geography (cf. linguistic geography). The products of this research are usually known as onomastic atlases (or name maps).

Areal onomastics started in the 1920s (for an overview of mainly German studies, see Kunze 1995 and Ramge 1995, and 
the methodology is discussed in Seibicke 2004; for Finnish, see e.g. the Place Names Atlas (paikannimikartasto) on the website of the Institute for the Languages of Finland (http://www.kotus. fi/index.phtml?s=383)). In Estonian, the first detailed name maps were published by Valdek Pall (1977: 189-226) in his monograph on the toponyms of northern Tartumaa. These include both name endings (suffixes) and frequent elements in names. A smaller selection of mapped name endings is given in Pajusalu et al. 2009: 281-286.

A geographical distribution of toponymic elements may help in understanding the chronological and spatial evolution of toponyms, and in finding connections that otherwise would remain unnoticed. Mapping the elements may also help to visualize and contrast the inventory of toponyms.

\section{Name corpus and selection principles}

In the following, an attempt is made to discover some patterns in the distribution of Estonian toponymic suffixes. As oikonyms (names of populated places) generally represent some of the oldest layers of toponyms, the selection of names is originally made up of some 10,100 names from the Place Names Database of the Institute of the Estonian Language (http://www.eki.ee/ $\mathrm{knab} / \mathrm{knab} . \mathrm{htm})$. These include names of towns, boroughs, villages, village parts, localities, city districts etc. To limit "noise" in the name corpus, homonymous names stemming from one location in one parish are reduced to just one occurrence, e.g. if there are villages and former settlements (asundus) with the same name (e.g. Kuimetsa asundus and Kuimetsa küla), only one name is included in the corpus. Also numbered populated places with the same name are reduced to one occurrence (e.g. for 1., 2., 3., 4. and 5. Maeru küla, only one is listed in the corpus). Names of village parts are omitted if they duplicate the main name (e.g. for Villevere küla there are the village parts Suur-Villevere and Väike-Villevere). However, if homonymous villages are official, e.g. Karilatsi küla in both Kõlleste and Vastse-Kuuste parishes, 
both are retained. Over all, it is estimated that there are roughly 9000 names in the final corpus; of these, $24 \%$ have the endings under study. (The number 9000 is an estimate, as the actual restriction was carried out only in the case of the name groups analysed.)

At this stage of the research, it is not possible to differentiate toponymic suffixes or formants from other name endings in all cases. Therefore, a kind of mechanical principle for recognizing suffixes has been chosen. A suffix is recognized if a name has more than three syllables (e.g. Aba/ja, Anger/ja, Kabi/ $\underline{n a}$ and $I m a / r a$ ), or two syllables and the Q3 degree of quantity (e.g. Ain/ja, Jäär/ja, Jaak/na and Oa/ra ). Again, names where the endings were clearly part of the word stem (e.g. Kadrin/a, Nigul/a and Margus/e) have been left out. In unclear cases, the decision was made in favour of recognizing suffixes.

The choice of suffixes is based on Kettunen 1955 and Pajusalu et al. 2009: 270-280, including almost all well-recognized suffixes and endings. These are grouped into three: suffixes that are recognized as words, less-used suffixes that might have very different origins, and finally, suffixes that are well-known and usually have one etymological origin. Under each toponymic suffix, a short summary of its main etymological groups is given, based on the sources mentioned.

\section{Word-like suffixes}

Toponyms with -jala (Fig. 1; 19 names) are originally 1) compound anthroponyms (e.g. Nahkjala and ?Mustjala), 2) compound appellatives (e.g. Hakjala and Puujala), or 3) toponyms with -jala as the determinative part (jalg "part of a field, hayfield etc.", e.g. Anijala and Tuhkjala). These toponyms are found mainly on the island of Saaremaa, significant pockets are also located in Harjumaa, and elsewhere the endings are found sporadically.

Toponyms with -lepa (Fig. 2; 26 names) have the ending mainly in two meanings: 1) "bay, inlet, cove" (cf. lópp : lõpe 
“id."); and 2) "alder". Fig. 2 makes it clear that most of the toponyms have the first meaning, as they are situated either at or not

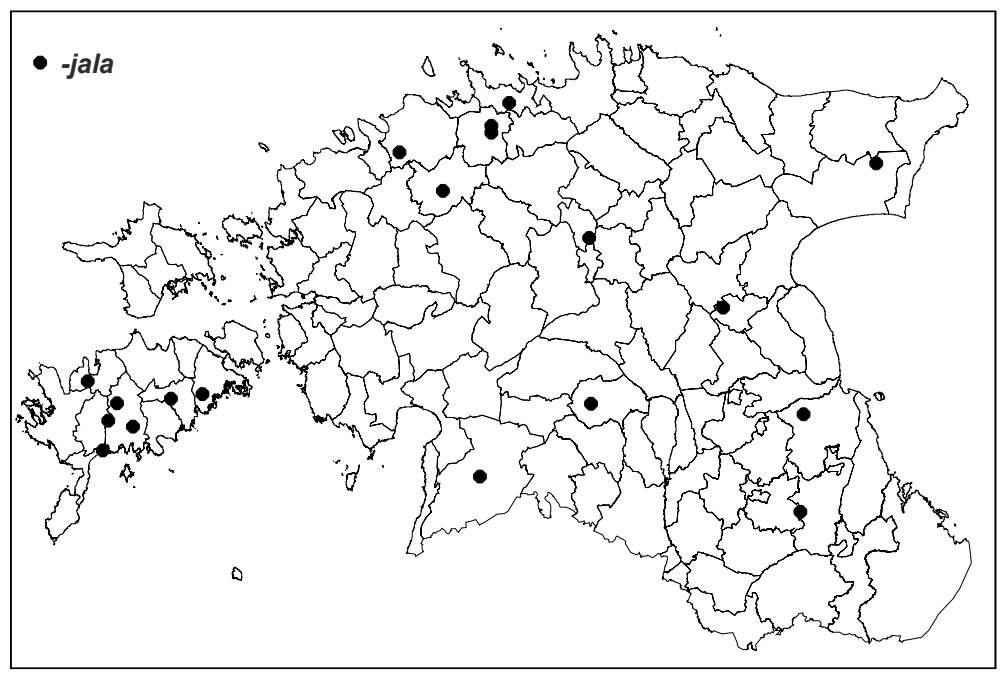

Figure 1. Toponyms with -jala.

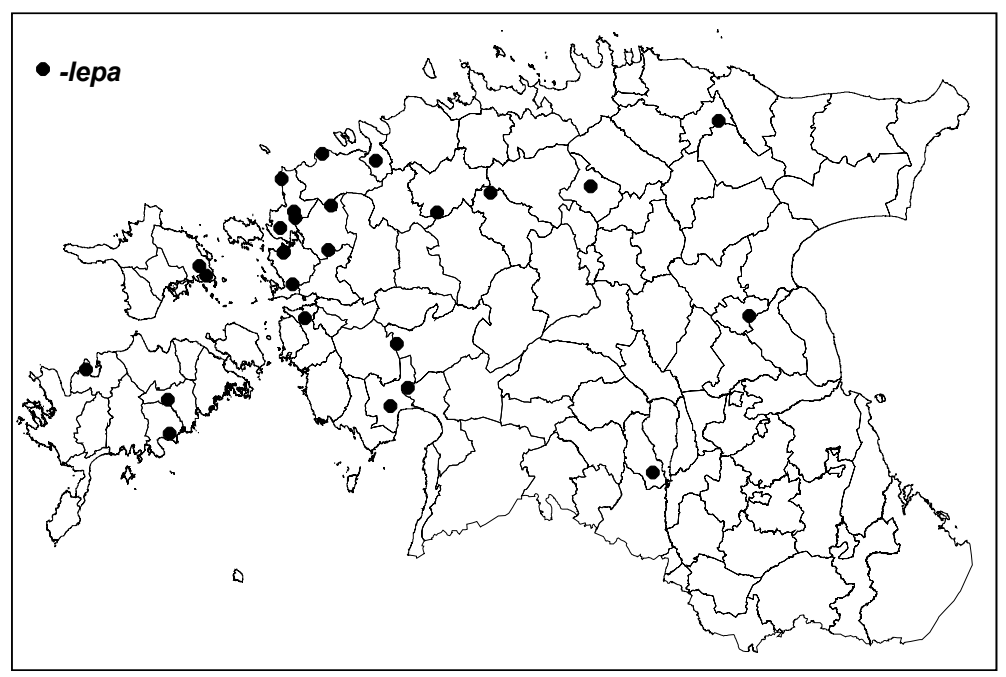

Figure 2. Toponyms with -lepa. 
far from the waterside. The ending is especially widespread in Läänemaa (e.g. Ridalepa, Sutlepa etc.).

Toponyms with -pea (Fig. 3; 57 names) come in three regional varieties: -pea is typical of northern Estonia (though in the local pronunciation it is often contracted to -pa, e.g. Letipea and Pärispea); -pää is widespread in eastern and south-eastern Estonia (e.g. Kasepää and Pahtpää), and -pe or -be is found on the islands, being pronounced with a wider $e(-p \varepsilon,-b \varepsilon$, e.g. Kudjape, Mäebe and Mänspe). Its main meaning is "head, end" and this explains why the toponyms are often found on the shoreline, especially in cape-like localities. Some of the toponyms may have originated from old anthroponyms. Fig. 3 shows that such names seem to occur mainly in south-eastern Estonia (e.g. Närapää and Otepää). Toponyms with a closely related suffix, - pa or -ba (26 names, e.g. Haiba and Vahtrepa), are often contracted forms of -peal-pää, but their distribution on the map (see Fig. 3) indicates that, apart from Pärnumaa (e.g. Saulepa), these toponyms are mainly found in inner areas, thus falling perhaps into the second etymological group of names deduced from anthroponyms.

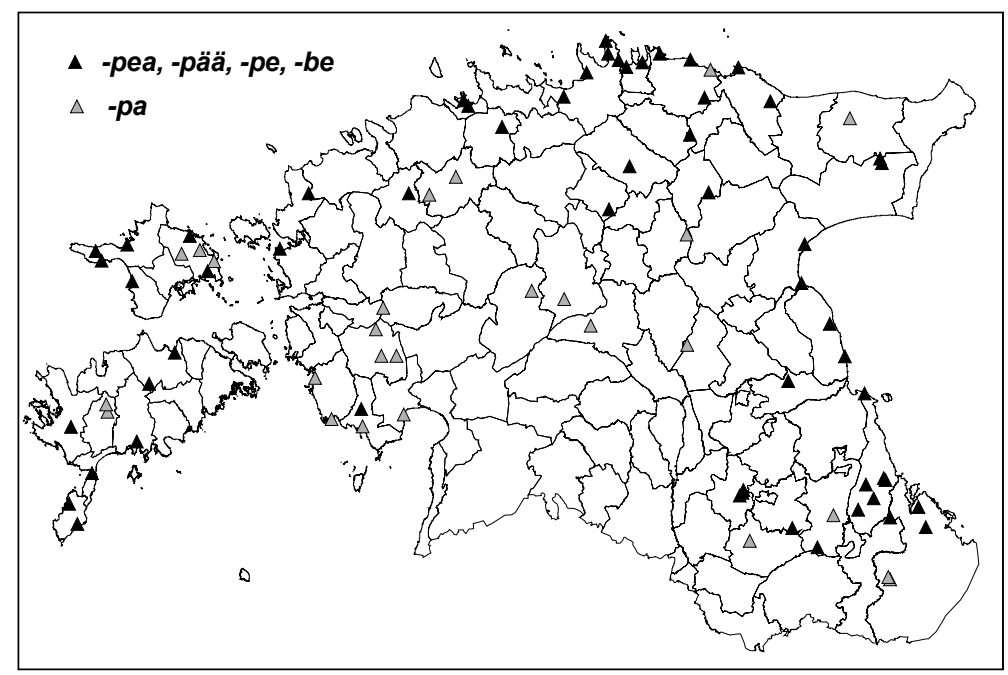

Figure 3. Toponyms with -pea, -pä̈, -pe, -be and -pa. 


\section{Polyetymological suffixes}

This group of toponyms contains endings that have several possible etymological sources. Often there are no specific areal patterns to be observed.

Toponyms with -ke (Fig. 4; 19 names) seem to be characteristic of south-eastern Estonia (e.g. Hänike, Lutike and Vidrike); possibly these are either names with the diminutive suffix $-k e(s e)$ or adaptations of personal names (e.g. Hänike $<$ Henning $<$ Heinrich). In other areas, toponyms with $-k e$ might be contracted forms (e.g. Sõtke $<$ *Sõtküla).

Toponyms with -ja or -jä (Fig. 5; 85 names) are a heterogeneous group, where the ending has several different sources. In quite a few toponyms, -ja might be a general deverbal or denominal suffix, e.g. in the names Pedja, Õmbleja and Tsilgutaja. Other sources of the suffix are contractions of the words -jala (e.g. Lehmja < *Lehmjala), -jõe (e.g. Anija < *Hanijõe), -oja (e.g. Saunja $<*$ Sau(e)noja) etc. A look at the map in Fig. 5 shows that there are no specific patterns in the distribution of the toponyms, although south-eastern Estonia and southern Harjumaa seem to have some concentration areas of the toponyms.

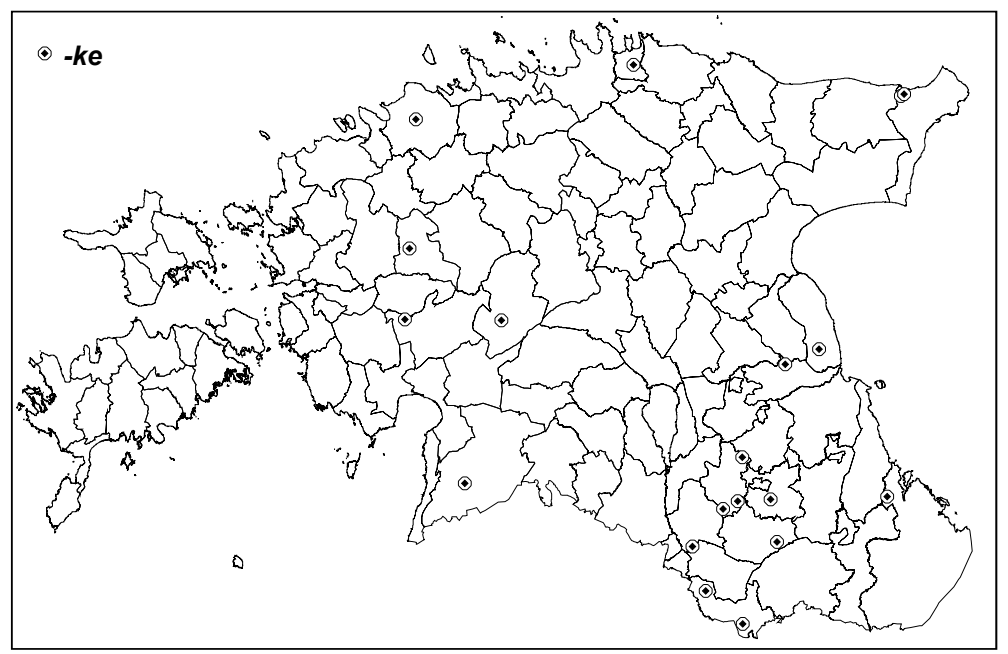

Figure 4. Toponyms with -ke. 
Toponyms with $-n a$ or $-n \ddot{a}$ (Fig. 6; 160 names) are also a heterogeneous group, where the ending might be a contraction of the words -kanna (e.g. Tammuna < *Tammekanna), -nina (e.g.

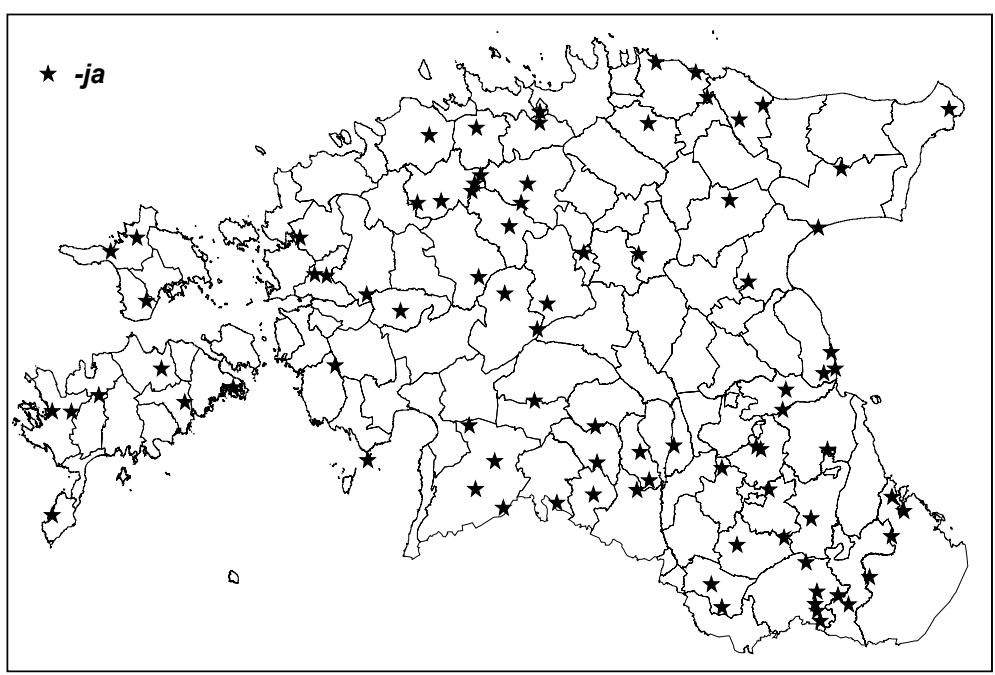

Figure 5. Toponyms with -ja.

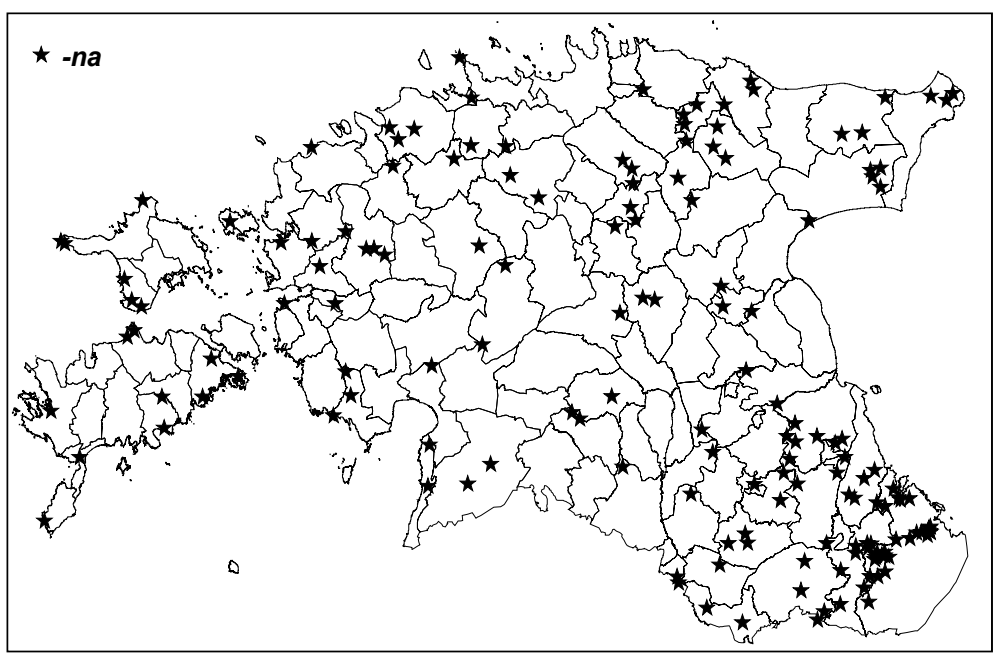

Figure 6. Toponyms with -na. 
Kalana $<*$ Kalanina), -n+oja (e.g. Vääna $<*$ Vägenoja), -ranna (e.g. Suurna $<*$ Suurranna), etc. Quite a few toponyms with $-n a$ are adaptations of Russian names (e.g. Kuksina $<$ Kuvšinovo, and Pitsinä < Spičino). A look at the map in Fig. 6 shows a massive presence of such names in Setumaa, and also a higher frequency in south-eastern Estonia in general. This may indicate possible Russian origins of the names.

Toponyms with -ra (Fig. 7; 65 names) are often contractions of the endings -aru (e.g. Läbara < * Läbaru), -järve (e.g. Tabara < *Tabijärve), -rahva (e.g. Metsara < *Metsarahva), -saare (e.g. Aitsra <*Aitsaare), -vare (e.g. Kiivera < *Kivivare), and -vere (e.g. Oara <*Ohavere, and Mädara <*Mädavere). The ending $-r a$ is rarely a suffix on its own (except perhaps in Mahtra). The toponyms are common mostly in south-eastern Estonia and in northern Pärnumaa.

Toponyms with -ma(a) (Fig. 8; 241 names) form a large group, where most of the endings were originally either -maa "land" (e.g. Kodismaa and Põltsamaa) or -mäe "hill" (e.g. Heltermaa $<*$ Heltermäe, and Vilama $<*$ Vilamäe); often the origin is debatable, as earlier recordings show both possibilities.

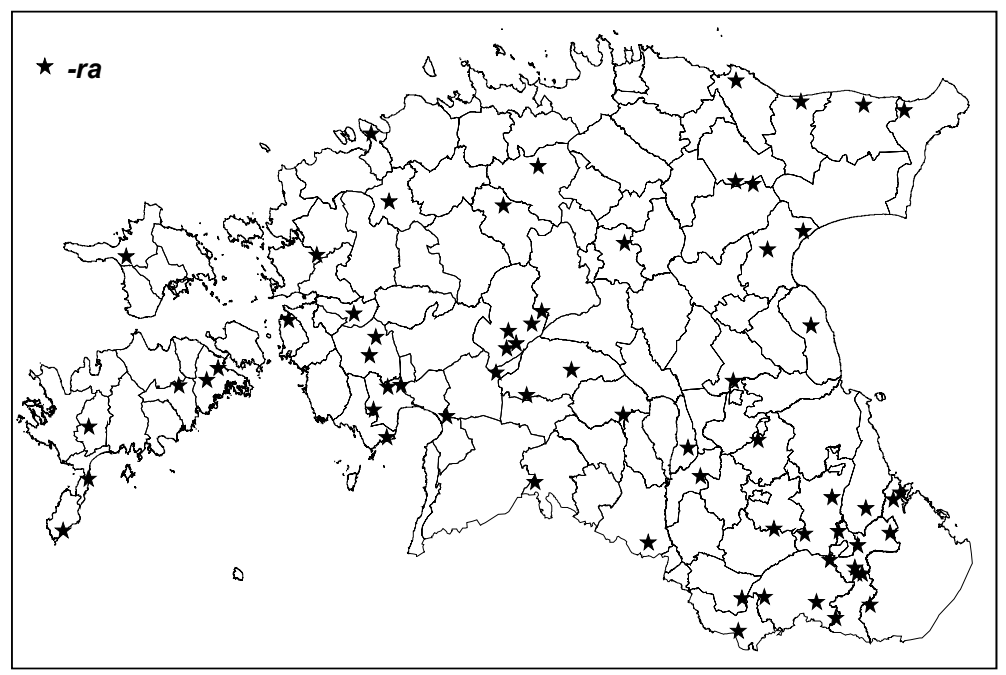

Figure 7. Toponyms with $-r a$. 


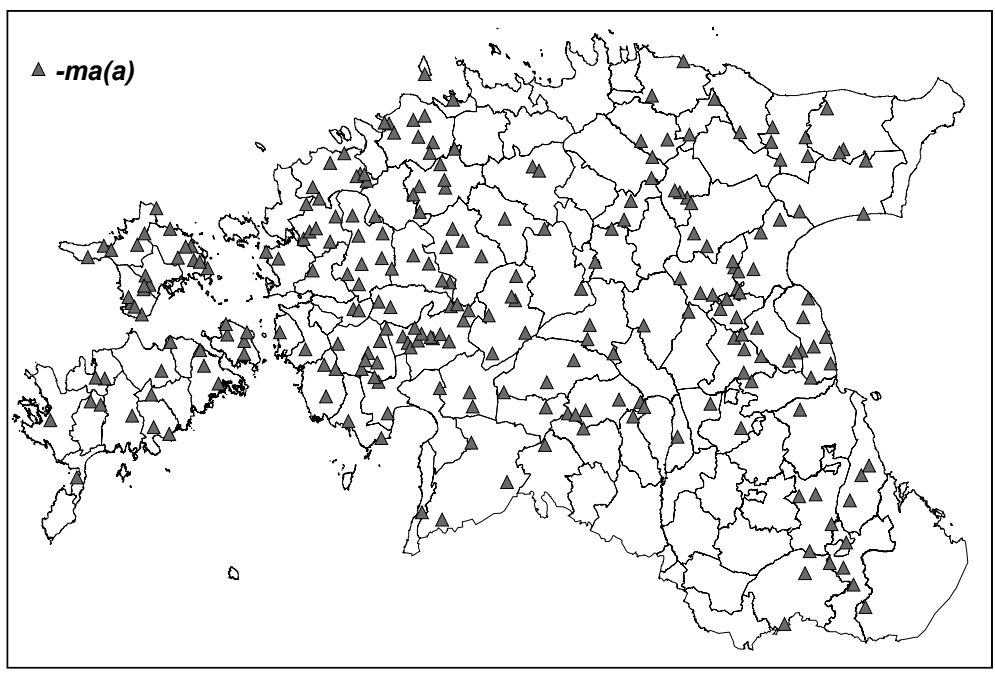

Figure 8. Toponyms with -ma(a).

Various other elements may also have been shortened to - $m a(a)$ : -aseme (e.g. Kodasema < *Kodaaseme), -metsa (e.g. Küdema $<$ *Küdemetsa), -nurme (e.g. Langerma $<*$ Langenurme), and -võhma (e.g. Kõrma < *Kõrvevõhma). The map in Fig. 8 shows that the toponyms are mainly found in the flat landscape of western, central and eastern Estonia; in hilly southern Estonia they are relatively scarce.

Toponyms with $-v a$ or $-v \ddot{a}$ (Fig. 9; 114 names) may have originated from several endings, e.g. -peal-pää (e.g. Keava < *Kädenpää, and Kiideva < *Kividepää), but most of the toponyms contain either deverbal (e.g. Orava) or denominal (e.g. ? Jõgeva) suffixes, or are difficult to etymologize (e.g. Tõdva). In south-eastern Estonia the toponyms with $-v a$ are usually adaptations from Russian (e.g. Antkruva < Andrjukovo, and Seretsüvä $<$ Žerebcovo). This explains their significant presence on the border with Russia. Otherwise, there are no significant concentration areas of the toponyms.

Toponyms with -tu (Fig. 10; 47 names) are mostly difficult to explain, although some names may contain either denominal suffixes (e.g. ? Puiatu and Raotu) or deverbal suffixes (e.g. 
? Pühatu). These toponyms seem to fall into isolated clusters all over Estonia.

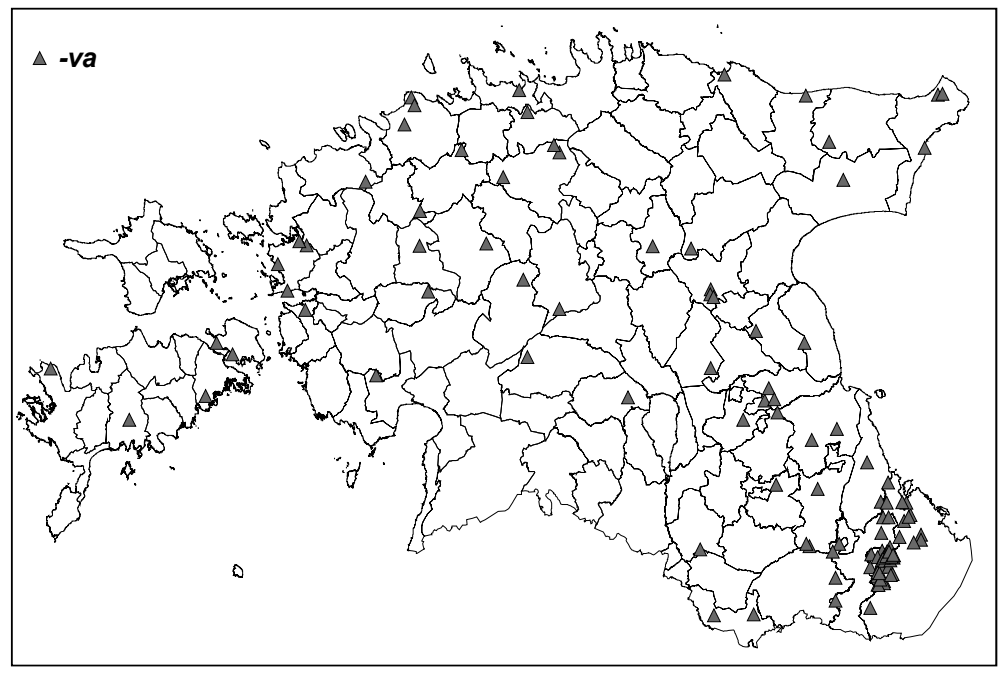

Figure 9. Toponyms with -va.

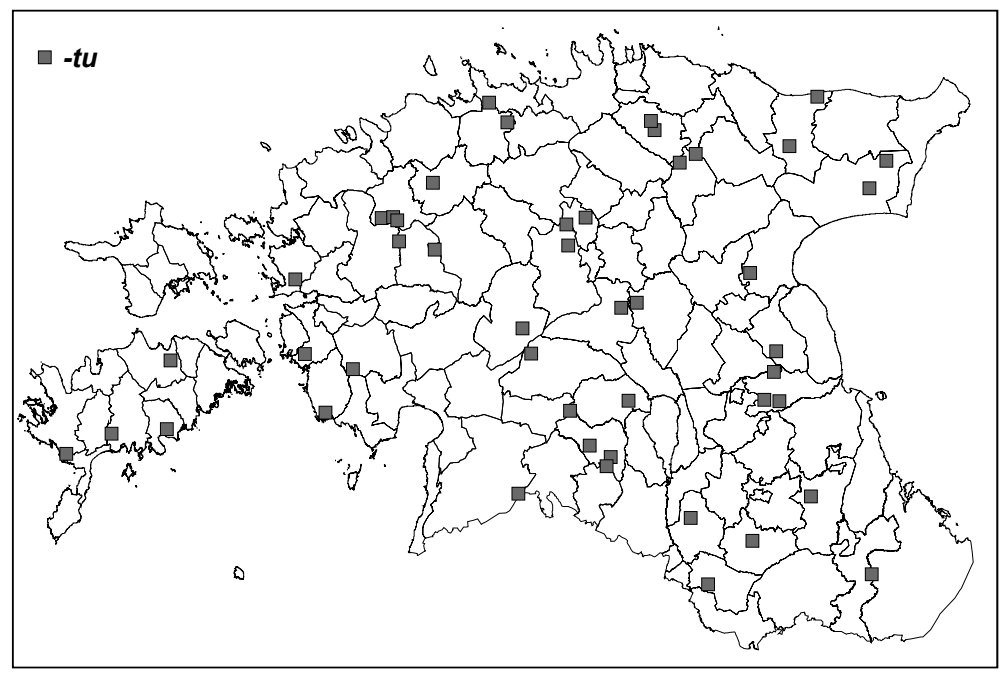

Figure 10. Toponyms with $-t u$. 


\section{Most used suffixes}

This group of toponyms contain suffixes that are most readily recognized in place names. As a rule, the endings have a single etymological source, although in some cases there are contractions of endings and thus the sources might also be different.

Toponyms with -stu (Fig. 11; 41 names) form a small group of names which may contain the collective suffix -stu (e.g. Salmistu and Tammistu). In other cases, there is some overlapping with toponyms ending with -ste (e.g. Kuivastu $\sim$ Kuivaste, and Kõinastu $\sim$ Keinaste) and the origins of those names may lie in other toponyms ending with -ste. The map in Fig. 11 shows some concentration areas of the toponyms: south-eastern Estonia, the border area of Harjumaa, Järvamaa and Pärnumaa, and some areas on the northern coast of Estonia. See also Fig. 14.

Toponyms with -se or -sõ (Fig. 12; 286 names) and -si (97 names) form a large group, where most of the names are originally those ending with -ne (e.g. Mägise and Rebase) or -s (e.g. Ilvese and Varese). While -se is a singular stem, -si reflects an

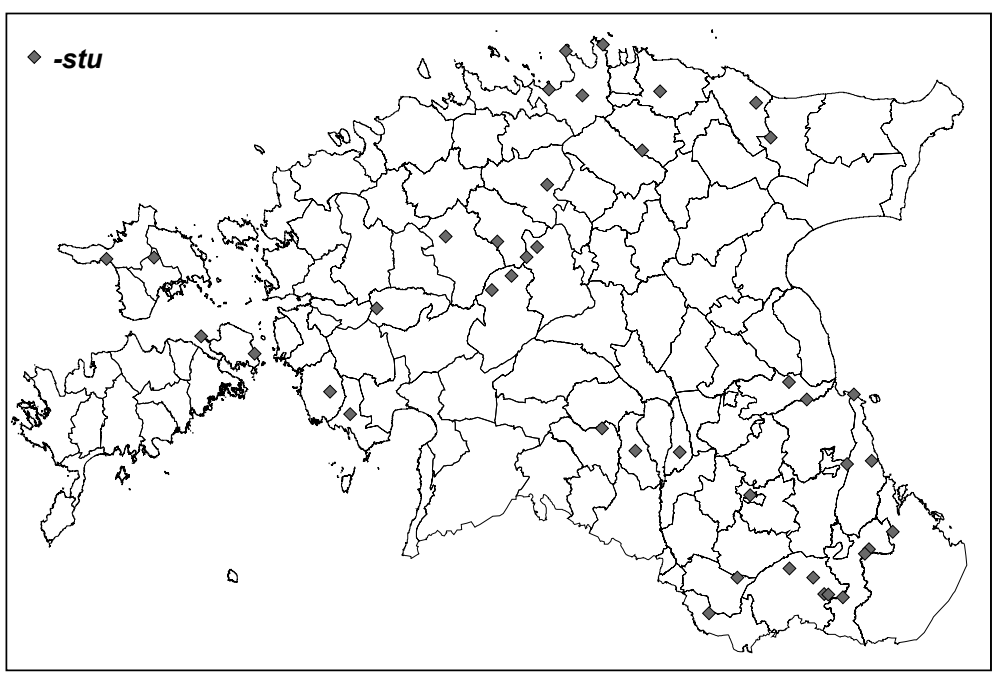

Figure 11. Toponyms with -stu. 


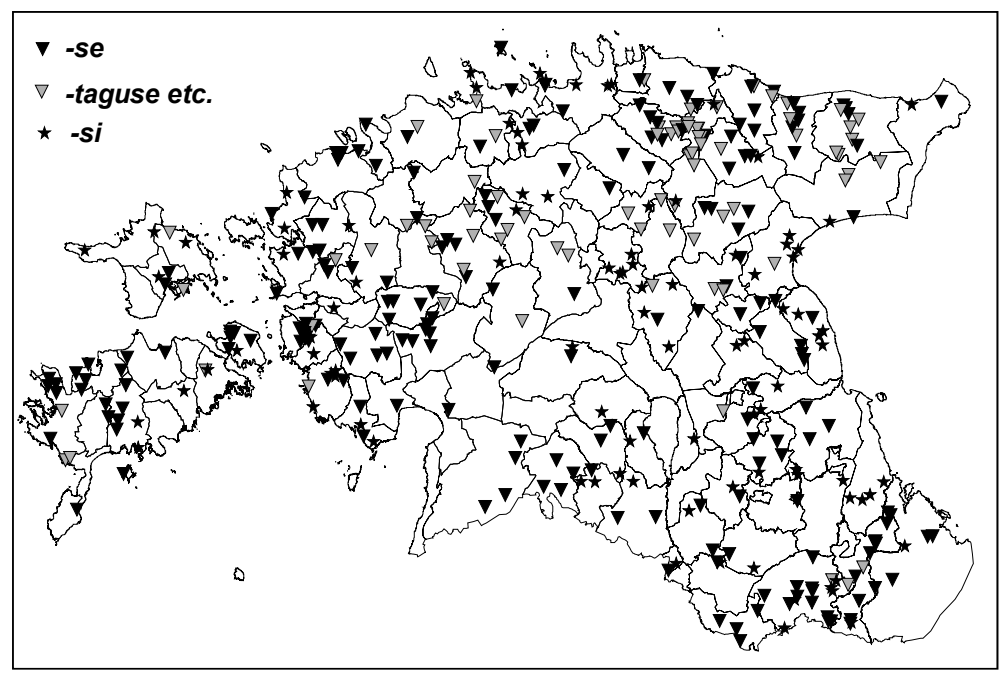

Figure 12. Toponyms with -se and -si.

originally plural stem. Modifications of the ending -se are -kse (e.g. Jalukse and Ännikse) and -tse (e.g. Külitse and Libatse), as well as the longer suffixes -kese (e.g. Talvikese) and -lase (e.g. Kuralase and Kimalasõ). In many toponyms with -se, there is a second component, such as -aluse "below" (e.g. Pajualuse), -pealse/-päälse "on, above" (e.g. Arupealse and Kerepäälse), -taguse "behind" (e.g. Väljataguse), or -äärse "at" (e.g. Ojaäärse) which usually indicates the relative position of the named feature (in Fig. 12, these toponyms are marked with a lighter filling). The toponyms with -se are evenly spread all over Estonia, except for northern Viljandimaa. Toponyms with -si are more characteristic of eastern and south-eastern Estonia, but they occur elsewhere as well.

Toponyms with -la (Fig. 13; 307 names) are one of the three largest groups, together with -ste and -vere; -la is a wellknown general suffix denoting location or a diminutive quality. Some toponyms with -la are contractions, where the ending might originally have been -jala (e.g. Sadala $<*$ Sadajala), -küla (e.g. Uugla $<*$ Uueküla), -valla (e.g. Jägala $<* J a ̈ g a v a l l a)$, -vilja (e.g. Vetla $<*$ Vetvilja) or -välja (e.g. Jõgela $<*$ Jõgevälja). As 


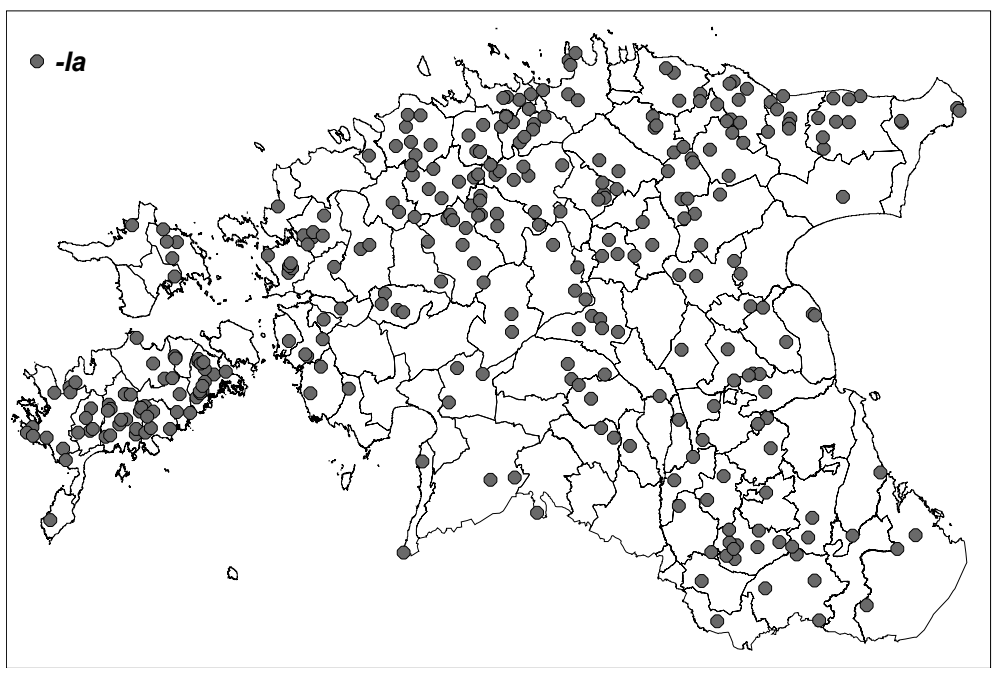

Figure 13. Toponyms with -la.

noted earlier by Valdek Pall (1977: 195-196), these toponyms are more typical of northern Estonia and Saaremaa and their distribution seems to extend from the west in Saaremaa to the northeast in Virumaa like an arc. There is also a less recognizable spread from the north in Harjumaa to the south-east in Vorrumaa.

Toponyms with -ste or -stõ (Fig. 14; 286 names) originated, like those with -se, from names and words ending in -ne (e.g. Hammaste and Ihaste) and -s (e.g. Jäneste, Kallaste and Vareste); the stem is in plural. A look at the map in Fig. 14 shows that the toponyms are characteristic of southern Estonia, especially the south-east. In Hiiumaa, the toponyms are sometimes late adaptations of Swedish names (e.g. Malvaste < Malmas). The spread of the toponyms seems to form a countering arc to the toponyms with - $l a$, extending from the south-east in Võrumaa to the northwest on the islands. The north-east contains very few toponyms with -ste.

Finally, the toponyms with -vere (Fig. 15; 308 names) still have a disputed origin, although onomasticians agree that the ending -vere was originally a topographic appellative, perhaps 
related to forestry. In some areas, e.g. Raplamaa, the -vere ending has transformed to -pere (e.g. Kaigepere and Lellapere) and therefore these names are also included in Fig. 15 (other -pere

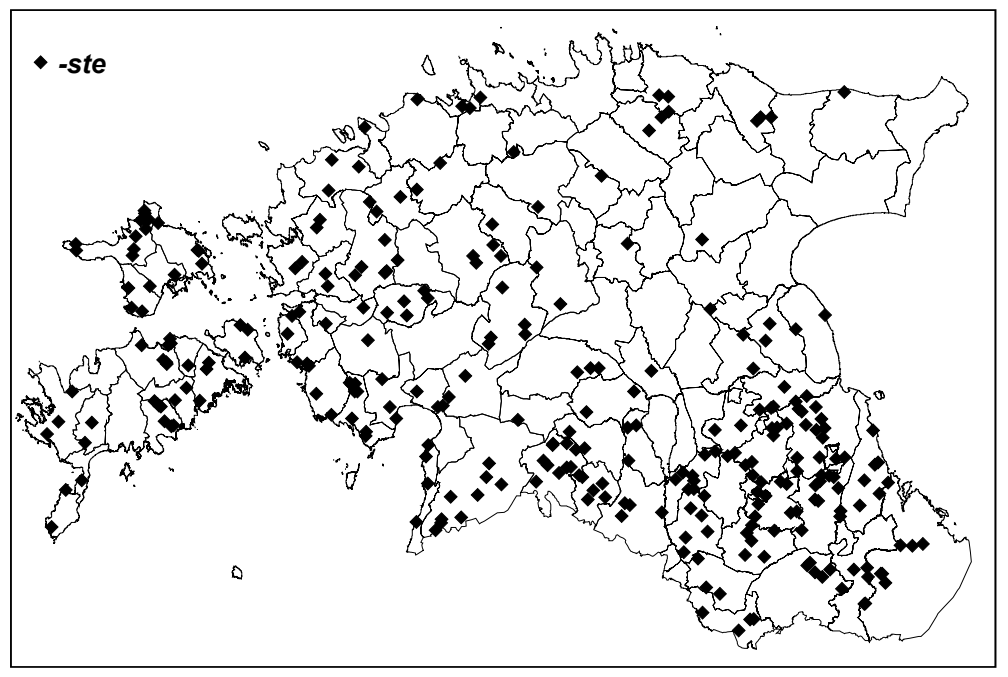

Figure 14. Toponyms with -ste.

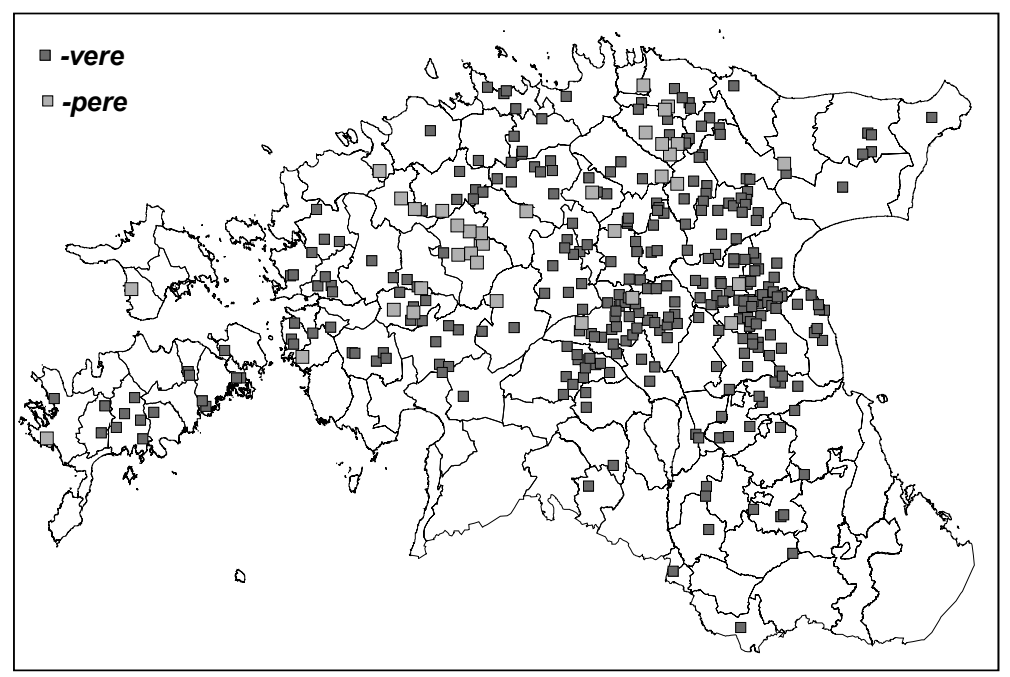

Figure 15. Toponyms with-vere and -pere. 
names might originate from the word pere 'family'). As noted by several onomasticians (see Pall 1977: 190-192), there is a clear concentration of the toponyms in northern Viljandimaa, northern Tartumaa and western Virumaa. While the toponyms are present in Harjumaa, Läänemaa and Saaremaa, they are not dominant there. In south-eastern Estonia toponyms with -vere are rare.

\section{Suffix domination areas}

This brings us to an interesting point related to the distribution of the three most used toponymic suffixes. Fig. 16 shows how the whole area of Estonia may be divided into different regions depending on dominant suffixes.

Northern Tartumaa and northern Viljandimaa form the region where toponyms with -vere are dominant, although toponyms with -la are also present. Toponyms with -ste are rare but a transition form of $-s t+$-vere (e.g. Pilistvere and Pupastvere) is common.

Southern Estonia (Võrumaa, southern Tartumaa, Viljandimaa and Pärnumaa) is the -ste region. Toponyms with -la are also present, especially in western Võrumaa, but toponyms with -vere are rare.

Northern Estonia (Harjumaa, Järvamaa and Virumaa) is the area of the domination of toponyms with -la. Toponyms with -vere are also present, especially in western Virumaa and some areas of Harjumaa, but toponyms with -ste are rare.

Apart from these distinct areas, western Estonia (Läänemaa and northern Pärnumaa) seems to be a mixed region, where none of the suffixes are prevalent. A special case is formed by the islands. Hiiumaa may be considered a mixed area, like Läänemaa, but toponyms with -ste are slightly more frequent. Saaremaa seems to be a clear -la region, although both -ste and -vere are present.

Whether these differences were caused by early settlement patterns or by some environmental reasons (which may be 


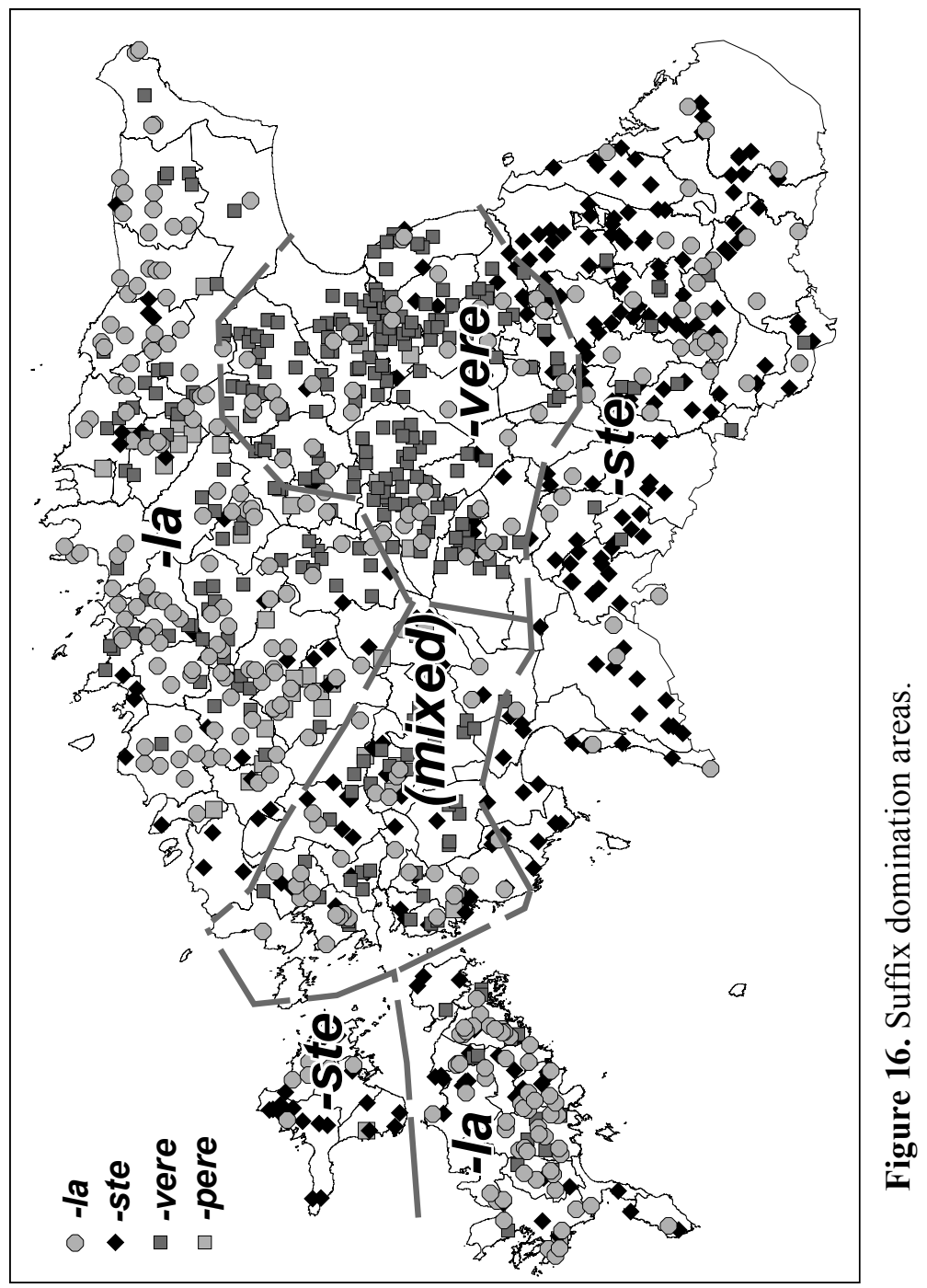


the case with -vere), it is still too early to say. Perhaps more understanding will come if we can add a chronological dimension to the toponyms; this might, for example, show the direction of the spread of toponyms. Also, names could then be analysed in their non-contracted forms, involving all toponyms where the original suffixes were either -la, -ste or -vere.

\section{Concluding remarks}

As might have been expected, toponyms with well-recognized suffixes display a certain distribution pattern in Estonia, so that in some of the areas specific suffixes are dominant. Those that have multiple origins tend to be distributed evenly all over Estonia, only some borrowed endings display (e.g. - va or $-n a)$ some distribution patterns having more frequency in border areas. The analysis of the geographical distribution of suffixes may help in further understanding the evolution and possible etymologies of the toponyms.

\section{Address:}

Peeter Päll

Institute of the Estonian Language

Roosikrantsi 6

10119 Tallinn, Estonia

E-mail: peeter.pall@eki.ee

\section{References}

Kettunen, Lauri (1955) Etymologische Untersuchung über estnische Ortsnamen. (Suomalaisen Tiedeakademian Toimituksia. Sarja B, nide 90, 1.) Helsinki.

Kunze, Konrad (1995) "Namengeographie als historische Hilfsdisziplin". In Namenforschung. Ein Internationales Handbuch zur Onomastik, 1065-1070. Berlin, New York: Walter de Gruyter.

Pajusalu, Karl, Tiit Hennoste, Ellen Niit, Peeter Päll, and Jüri Viikberg (2009). In Eesti murded ja kohanimed. 2 rev. ed. Tiit Hennoste, ed. Tallinn: Eesti Keele Sihtasutus. 
Pall, Valdek (1977) Põhja-Tartumaa kohanimed 2. Madis Norvik, ed. Tallinn: Valgus.

Ramge, Hans (1995) "Arbeits- und Darstellungstechniken der Namenforschung: Atlanten." In Namenforschung. Ein Internationales Handbuch zur Onomastik, 312-317. Berlin, New York: Walter de Gruyter.

Seibicke, Wilfried (2004) "Areallinguistische Methoden der Namenforschung". In Namenarten und ihre Entforschung, 185-211. Andrea Brendler und Silvio Brendler, Hrsg. Hamburg: Baar.

Kokkuvõte. Peeter Päll: Eesti kohanimelõppude leviku vaatlusi. Artikkel käsitleb Eesti kohanimelõppude geograafilist levikut ja püüab sedastada selle seaduspärasusi. Vaatluse all on u 9000 asulanime lõpud, millest analüüsitav materjal hõlmab 24\%. Kohanimelõppe on arvestatud neis nimedes, mis on vähemalt 3 -silbilised või on 2-silbilised ja III vältes; nende puhul on tõenäoliselt tegemist tuletusliitega. Nende lõppude puhul, mis on etümoloogiliselt mitme lähtega (lühenenud sõnadest jms), ei ole geograafilisel levikul üldiselt mingeid selgeid mustreid (v.a mõned laenulised lõpud, nagu -va või -na). Tüüpiliste kohanimelõppude -la, -ste ja -vere puhul on aga märgata nende selgemat koondumist mingile alale, mille alusel saab Eesti jagada mitmesse piirkonda: -vere-ala (Põhja-Tartumaa ja Põhja-Viljandimaa), -ste-ala (Võrumaa, Lõuna-Tartumaa, Lõuna-Viljandimaa, Lõuna-Pärnumaa), -la-ala (Virumaa, Järvamaa, Harjumaa) ning segaala (Läänemaa, Põhja-Pärnumaa). Saaremaa on valdavalt -la-ala, Hiiumaa aga kas segaala või -ste-ala.

Märksõnad: kohanimed, kohanimesufiksid, kohanimegeograafia, etümoloogia 